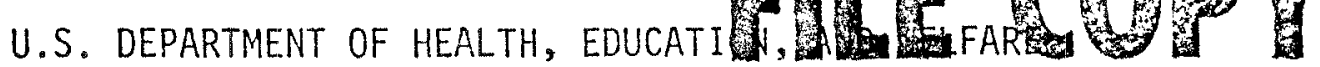 \\ rLIE
} CENTER FOR DISEASE CONTROL

NATIONAL INSTITUTE FOR OCCUPATIONAL SAFETY AND HEALTH CINCINNATI, OHIO 45202

\author{
HEALTH HAZARD EVALUATION DETERMINATION \\ REPORT NO. 75-108, $111,113-248$ \\ FAIRBANKS WEIGHING DIVISION; COLT INDUSTRIES \\ ST. JOHNSBURY, VERMONT \\ DECEMBER 1975
}

\section{TOXICITY DETERMINATION}

It has been determined that a health hazard due to an epoxy resin and an aliphatic amine do not exist in the electronic production area. It has also been determined that metal fumes and ozone from the Plasama arc cutting operation does not pose a health hazard at the concentrations measured. Also, it has been determined that spray painters are not exposed to toxic concentration of organic vapors from the paint solvents.

These determinations are based on observations made during the environmental survey conducted July 28-30, 1975, environmental samples collected during this same period, and lack of adverse medical symptomatology.

II. DISTRIBUTION AND AVAILABILITY OF DETERMINATION REPORT

Copies of this Determination Report are availale upon request from the Hazard Evaluation Services Branch, NIOSH, U.S. Post Office Building, Room 508, 5th and Walnut Streets, Cincinnati, Ohio 45202. Copies have been sent to:

a) Fairbanks Weighing Division, Colt Industries, St. Johnsbury, Vermont

b) Authorized Representative of Employees

c) U.S. Department of Labor - Region I

d) NIOSH - Region I

For the purpose of informing the affected employees the employer shall promptly "post" the Determination Report in a prominent place(s) near where exposed employees work for a period of 30 calendar days.

III. INTRODUCTION

Section 20(a)(6) of the Occupational Safety and Health Act of 1970, 29 U.S.C. 669(a)(6), authorizes the Secretary of Health, Education, and Welfare, following a written request by any employer or authorized representative of employees, to determine whether any substance normally found in the place of employment has potentially toxic effects in such concentrations as used or found. 
Page 2 - Health Hazard Evaluation Determination 75-108, 111, 113

The National Institute for Occupational Safety and Health (NIOSH) received seven requests from an employer representative regarding employee exposure to potentially toxic substances while conducting assigned operatjons in respective work areas. Three of these requests were in regard to employee exposure to 1) an epoxy resin and an aliphatic amine used in the electronic department (RHE 75-108), 2) ozone and metal fumes from the plasma arc cutting operation, (RHE 75-111), and 3) organic vapor from the paint solvents used for spray painting (RHE 75-113). The substances of concern in the other areas (requests 75-109, 110, 112, and 114) are currentiy under further investigation and will be reported at a later date:

IV. HEALTH HAZARD EVALUATION

\section{A. Plant Process - Conditions of Use}

The Fairbanks Weighing Division, Colt Industries, St. Johnsbury, Vermont plant is engaged in the manufacturing of more than one hundred different models of weighing scales. This is accomplished by conducting specific operations at designated locations in one large building $\left(690^{\prime} \times 280^{\prime}\right.$ with relatively high ceilings). Potentially toxic substances were identified in three separate operations.

The potential health hazard in the electronics area was due to vapors from an epoxy resin and an aliphatic amine.

A two part "potting compound" is reportedly mixed (48 0z./batch, 2 batches/day at the most) by one employee. The mixture is then used to water encapsulate strain gages on an axle used in weighing scales. Such axles are generally used to weigh out feeds mixed in feed mixers; the strain gage translates strain into pounds through an electronic signal. This operation is reportedly conducted at a workbench in a large open area. No local exhaust is present in the immediate work area but portable air circulating fans are used freely.

In the second operation of concern, the potential health hazard was due to ozone and metal fumes generated by a plasma arc cutting operation.

The cutting operation is semi-automatic and requires minimal attention. One employee positions the metal to be cut on a plenum box (local exhaust system) and then proceeds to initiate the cutting by push button controls located on an adjacent control panel.

The down draft local exhaust system is provided through the plenum box which also serves to hold the metal being cut. Two five inch ducts are located near the bottom of the box. The slot is adjustable since it is formed by placing pieces of scrap metal across the top of the plenum box.

The potential health hazard identified in the third operation was due to organic solvent used in spray painting.

Spray painting was conducted by three painters in three separate spray paint booths. Two of these booths are large $\left(20^{\prime} \times 12^{\prime} \times 8^{\prime}\right)$ water curtain type booths used for production type painting. A continuously moving conveyor passes through both of these booths. The third booth 
Page 3 - Health Hazard Evaluation Determination 75-108, 111, 113

$\left(13^{\prime} \times 10^{\prime} \times 8^{\prime}\right)$ is equipped with a bank of filters along the back wall. This booth is also equipped with a pressure gage used to determine the pressure differential (across the filter) which in turn is used to determine when the filters should be changed.

It was estimated that 50 gallons of paint and 10 gallons of additional thinner was used between the three spray painters each day.

\section{B. Evaluation Progress}

An initial survey was conducted on July $28-30,1975$. This included a walk-through survey of those areas in question, holding a brief meeting for the purpose of obtaining background information, collecting environmental air samples where deemed necessary, and administering confidential medical questionnaires.

\section{Evaluation Methods}

Exposure to the epoxy resin and aliphatic amine in question was not observed since the materials in question were not used during the survey. Instead, a description of the operation was obtained, and a physical inspection of the location where the materials are used was conducted. Also, the quantity of materials used in the past and projected useage was obtained.

Exposure to ozone and metal fumes from the plasma arc cutting operation was evaluated by collecting samples during a half hour demonstration.

Ozone concentrations were measured by utilizing detector tubes. Measurements were made as close to the workers breathing zone as possible.

A metal fume sample was collected at 2.5 Titers per minute on a polyviny chloride filter with the aid of a portable battery operated pump. The filter was weighed before and after collecting the sample and was analyzed for iron, manganese, chrome, nickel, and copper by atomic absorption. Ventilation measurements of the local exhaust system were made with an Alnor velometer.

The potential health hazard (exposure to solvent vapors) in the third request was evaluated by collecting breathing zone samples on charcoal tubes. These samples were collected at a flow rate that would yield a total volume of approximately ten liters for each charcoal tube. The three painters' exposure was determined on two consecutive days for the duration of their exposure. These samples were analyzed by gas chromatography.

In addition to the environmental evaluation, a confidential medical questionnaire was administered to those employees working in those areas of concern. The questionnaire consists of non-directed questions; however, a more direct line of questioning was also utilized in order to detect any adverse medical symptomatology which was possiblly due to the work environment. 
Page 4 - Health Hazard Evaluation Determination 75-708, 111, 113

D. Evaluation Criteria

a. Environmental Criteria

The three primary sources of environmental criteria considered in this report are (1) NIOSH criteria documents recommending occupational health standards (2) American Conference of Governmental Industrial Hygientsts (ACGIH) Threshold Limit Values (TLV) and (3) Federal Occupational Health Standards promulgated by the U.S. Department of Labor (Federal Register, June 27, 1974, Vol. 39, No. 125; Title 29, Chapter XVIII, Part 1910, Subpart G, Tables GI). Since the determinations made as a result of this evaluation would not be changed by listing all applicable recommended standards, TLVs, or Federal standard, only those considered most applicable are listed along with its source.

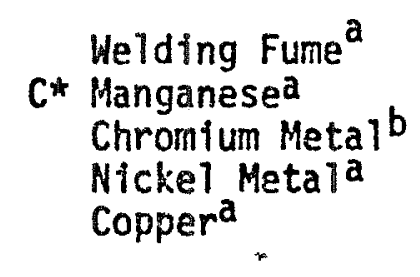

Ozonea

Xylenec 2-Ethoxyethanol ${ }^{a}$ Toluened
Time Weighted Average (TWA) in Milligrams per Cubic Meter

5
5
1
1
0.2

Time Heighted Average in Parts per Million (ppm)

a) ACGIH Threshold Limit Values for Chemical Substances in Workroom Air Adapted by ACGIH for 1975 and Supporting Documentation

*C means ceiling value

b) Federal Occupational Health Standards, June 27, 1974

c) NIOSH Criteria for a Recommended Standard... Occupational Exposure to Xylene, 1975

* $100 \mathrm{ppm}$ is an 8-hour TWA; a standard of $200 \mathrm{ppm}$ is recommended for a 10 minute period

d) NIOSH Criteria for a Recomended Standard... Occupational Exposure to Toluene, 1973

\section{b. Physiological Effects}

The following is a summary of the adverse effects resulting from excessive exposure to each of the substances of concern:

Amines - the physiological effects of Amines are largely those of its Tocal action; particularly dermatitis upon contact. Exposure to elevated vapor concentrations may produce irritation of the eyes, nose, and throat. Sensitization of the respiratory tract is also a possibility. 
Page 5 - Health Hazard Evaluation Determination $75-108,111,113$

Welding Fumes - metal fume fever is a possibility upon exposure to welding fumes; however, this is highly dependent on the metals and concentrations involved. Iron oxide is considered relatively inert. Prolonged excessive exposure to $\mathrm{Fe}_{2} \mathrm{O}_{3}$ may result in siderosis (a benign pneumoconiosis); which is simply an iron pigmentation. Copper

is more toxic and capable of producing metal fume fever. Still more toxic are nickel, chromium and manganese.

Some of the symptoms of metal fume fever include chills and fever, which rarely exceeds a temperature of $102^{\circ} \mathrm{F}$, upset stomach and vomiting, dryness of the throat, cough, weakness, and aching of the head and body. Such symptoms often occur some hours later and usually last only a day.

Ozone $\left(\mathrm{O}_{3}\right)$ - when exposed to very low concentrations of ozone for even brief periods of time, an individual may notice a pungent, sharp odor. As the concentration of ozone increases, the odor often seems to lessen. One then may experience irritation to the eyes, dryness of the nose and throat, and cough. If the ozone concentration continues to rise more severe symptoms may develop. These may include headache, upset stomach or vomiting, pain or tightness in the chest, shortness of breath, or tiredness, or weight los's which may last for several days to weeks. Finally, with higher levels of exposure lung edema and hemorrhage, and ultimately death, may take place if the individual continues his exposure.

Toluene - prolonged excessive exposure to this agent may acutely cause headache, weakness, fatigue, unconsciousness, loss of coordination, nausea, vomiting, anorexia, acute dermatitis and irritation of skin and mucous membranes.

Xylene - Excessive exposure to xylene may cause dermatitis, irritation of mucous membranes, nausea, vomiting, anorexia and heart burn. Dizziness, incoordination and a staggering gait may also occur.

2-Ethoxyethanol - This agent is not significantly irritating to the skin, somewhat irritating to the eyes and mucous membranes, readily absorbed through the skin, and has a low order of toxicity when inhaled.

\section{E. Evaluation Results and Discussion}

As stated earlier, actual use of the epoxy resin and aliphatic amine were not observed since the materials in question were not used during the initial survey. As it turned out, only 14-15 pounds of the mixture had been used since the initiation of the process (4-6 months prior to our visit). The process had not been conducted for at least two months and it was not definite as to when it would be conducted again. Also, the employee who had used the materfal had not experienced any adverse medical symptomatology.

Since there was no exposure, there was definitely no health hazard present during the initial survey. Should these materials be used again at the same location and in the sarne manner, it is not likely that an 
Page 6 - Health Hazard Evaluation Determination 75-108, 111,113

elevated amine vapor concentration will be generated. The reas $n$ for this is that the volume of the area is quite large and a portable air circulating fan was present to aid in dispersing the vapors. The possibility of contact dermatitis is always present when using these materials.

Ozone was not detected in the worker's breathing zone during the plasma arc cutting demonstration. It was not detected even after drawing twice as much air (through the detector tubes) as the manufacturer suggests. Also, the welding fume sample collected during the half hour demonstration was not significantly different from the blanks, either in weight or in metal content. There was no visable fume during the cutting and the local exhaust system was judged to be adequate.

Air velocity at the face of the two $5^{\prime \prime}$ ducts was 1000 feet per minute (fpm) and the slot velocity was $70 \mathrm{fpm}$ at the center of the slot and $50 \mathrm{fpm}$ toward the outer edges. As stated earlier the slot size is adjustable and is formed with scrap pieces of metal. The slot was 3-4" wide during these measurements but was much narrower during the actual cutting, thus the slot velocity was actually greater during cutting.

In addition to low levels of contaminants ard adequate local exhaust it was learned that the plasma arc cutting operation is seldom ever conducted. No cutting was scheduled during our visit, instead a half hour demonstration was conducted. For these reasons it was determined that the plasma arc cutting operation does not pose a health hazard.

The third request (75-113) was in regard to organic solvents used in a "hot airless" spray painting operation. This operation was reportedly conducted in the spray paint booth equipped with the bank of filters; however, during our visit the three painters conducted spray painting while utilizing compressed air.

The samples collected in the painter's respective bre?thing zones were analyzed for xylene, 2-ethoxyethanol, methy ethyi ketone, isopropanol, isobutyl alcohol, toluene, and benzene. Only xylene, 2-ethoxythanol, and toluene are reported in Table I because the others were not detected on the samples. The three that are reported were present in very low concentration (see Table I). Such concentrations are considered non-toxic. Also, the three booths were adequately ventilated; the average flow rate measured was greater than $100 \mathrm{fpm}$ in each case. In addition to this, the painters did not report having experienced an adverse medical symptomatology. For these reasons, it was determined that a health hazard did not exist.

V. REFERENCES

1. ACGIH; Threshold Limit Values for Chemical Substances in Workroom Air Adopted by ACGIH for 1975 and Supporting Documentation.

2. Federal Register, June 27, 1974 Vol. 39, No. 125; Title 29, Chapter XVIII, Part 19110, Subpart G, Tables G1. 
Page 7 - Health Hazard Evaluation Determination 75-108, 111, 113

3. NIOSH Criteria for a Recommended Standard...Occupationat Exposure to Xylene.

4. NIOSH Criteria for a Recommended Standard...Occupational Exposure to Toluene.

5. Patty, F.; Industrial Hygiene and Toxicology, Vol. II, 1967.

6. U.S. DHEW, Preventing Dermatitis if you Work With Epoxy Resins; Publication \#74-130, 1974.

7. U.S. DHEW, Industrial Exposure to Ozone, 1973.

8. American Welding Society; The Welding Environment, 1973.

VI. AUTHORSHIP AND ACKNOWLEDGEMENT

Report Prepared By:

Raymiond 0. Rivera

Industrial Hygienist

Hazard Evaluation Services Branch

Cincinnati, Ohio

Originating office:

Jerome P. Flesch, Chief

Hazard Evaluation Services Branch Cincinnati, Ohio

Acknowledgements

Environmental Evaluation:

Jack 0. Geissert

Industrial Hygienist

Hazard Evaluation Services Branch

Cincinnati, Ohio

John R. Kominsky

Industrial Hygienist

Hazard Evaluation Services Branch

Cincinnati, Ohio 
TABLE I

ORGANIC VAPOR CONCENTRATIONS IN PAINTERS' BREATHING ZONE

JULY $29-30,1975$

\begin{tabular}{|c|c|c|c|c|c|c|c|}
\hline Sample \# & Job Classification & Date & Time & $\begin{array}{l}\text { TWA } \\
\text { Xylene }\end{array}$ & $\begin{array}{l}\text { Concentration in } \\
\text { 2-ethoxyethanot }\end{array}$ & PPM & Comments \\
\hline $\begin{array}{l}2 \\
5\end{array}$ & Painter (A) & $07 / 29 / 75$ & $\begin{array}{l}0724-1200 \\
1308-1543\end{array}$ & $\begin{array}{l}0.1 \\
\text { N.n. }\end{array}$ & $\begin{array}{l}\text { N.D. } \\
1.2\end{array}$ & $\begin{array}{l}0.5 \\
\text { N.D. }\end{array}$ & Finish booth - water curtain \\
\hline $\begin{array}{l}3 \\
4\end{array}$ & Painter (B) & $07 / 29 / 75$ & $\begin{array}{l}0728-1200 \\
1310-1545\end{array}$ & $\begin{array}{l}0.7 \\
\text { N.D. }\end{array}$ & $\begin{array}{l}0.4 \\
1.5\end{array}$ & $\begin{array}{l}\text { N.D. } \\
1.9\end{array}$ & 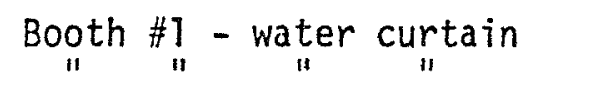 \\
\hline $\begin{array}{l}1 \\
6\end{array}$ & Painter (C) & $07 / 29 / 75$ & $\begin{array}{l}0731-1153 \\
1315-1539\end{array}$ & $\begin{array}{l}0.3 \\
\text { N.D. }\end{array}$ & $\begin{array}{l}0.5 \\
1.4\end{array}$ & $\begin{array}{l}\text { N.D. } \\
\text { N.D. }\end{array}$ & Dept. $753-$ Filiters \\
\hline $\begin{array}{l}\text { CT }-10 \\
\text { CT }-13\end{array}$ & Painter (B) & $07 / 30 / 75$ & $\begin{array}{l}0701-1141 \\
1312-1553\end{array}$ & $\begin{array}{l}N . D \text {. } \\
0.7\end{array}$ & $\begin{array}{l}0.3 \\
0.6\end{array}$ & $\begin{array}{l}1.4 \\
\text { N.D. }\end{array}$ & $\underset{\|}{\text { Booth } \# 1 \text { - water curtain }}$ \\
\hline $\begin{array}{l}\mathrm{CT}-11 \\
\mathrm{CT}-14\end{array}$ & Painter (A) & $07 / 30 / 75$ & $\begin{array}{l}0702-1138 \\
1312-1554\end{array}$ & $\begin{array}{l}\text { N.D. } \\
0.2\end{array}$ & $\begin{array}{l}0.3 \\
0.5\end{array}$ & $\begin{array}{l}\text { N.D. } \\
0.7\end{array}$ & Finish ${ }_{11}{ }_{1}$ \\
\hline $\begin{array}{l}C T-12 \\
C T-15\end{array}$ & Painter (C) & $07 / 30 / 75$ & $\begin{array}{l}0711-1127 \\
1318-1555\end{array}$ & $\begin{array}{l}\text { N.D. } \\
0.3\end{array}$ & $\begin{array}{l}0.7 \\
1.1\end{array}$ & $\begin{array}{l}0.7 \\
\text { N.D. }\end{array}$ & $\underset{1 "}{\text { Dept. }} \underset{\text { " }}{753}-$ Filters \\
\hline
\end{tabular}

1.D. - None detected, detection limit is $0.01 \mathrm{mg} / \mathrm{sample}$ 